POLIIICAL ECONOMY RESEARCH INSIITUTE

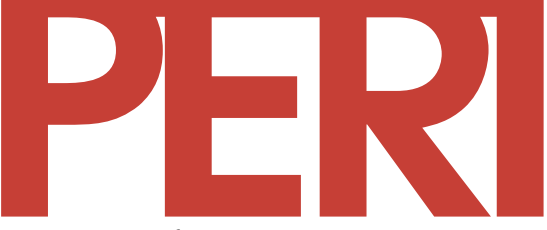

University of Massachusetts Amherst

\title{
Green and Brown? Globalization and the Environment
}

\author{
James Boyce
}

2004

10th floor Thompson Hall University of Massachusetts Amherst, MA, 01003-7510 Telephone: (413) 545-6355 Facsimile: (413) 545-2921

Email:peri@econs.umass.edu Website:

http://www.umass.edu/peri/

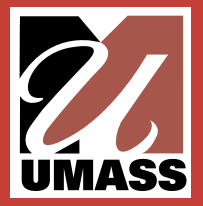




\title{
GREEN AND BROWN?
}

\section{GLOBALIZATION AND THE ENVIRONMENT}

\author{
James K. Boyce *
}

\begin{abstract}
Globalization - viewed as a process of economic integration that embraces governance as well as markets - could lead to worldwide convergence toward higher or lower environmental quality, or to environmental polarization in which the 'greening' of the global North is accompanied by the 'browning' of the global South. The outcome will not be dictated by an inexorable logic. Rather it will depend on how the opportunities created by globalization alter balances of power within countries and among them.
\end{abstract}

\section{INTRODUCTION}

In the early 1990s, the environmental movement in the United States underwent an acrimonious split over whether to support the proposed North American Free Trade Agreement (NAFTA). Some groups backed the treaty, agreeing that 'the best way to ensure that Mexico's environment is cleaned up is to help Mexico become a prosperous country, and that means NAFTA." ${ }^{1}$ Others opposed it, arguing that 'the competition to attract investment will result in a lowest common denominator for environmental statutes' and that 'the country with the least restrictive statutes will become the floor, and others will harmonize downward to that floor.'

Despite their differences, both sides shared a common assumption: Mexico's environmental practices were inferior to those of the U.S. and Canada. The only point of contention was whether free trade would pull the U.S. and Canada down to Mexico's level, or lift Mexico to the plane of its northern neighbors. Partly as a result, both sides were oblivious to what may turn out to be NAFTA's most serious environmental impact: the erosion of Mexico's rich biological diversity in maize ('corn' in U.S. parlance), as Mexican campesino farmers abandon traditional agriculture in the face of competition from cheap corn imported from the U.S. ${ }^{3}$

In this paper, I question the assumption the global North is relatively 'green' and the global South relatively 'brown.' I also argue neither theoretical reasoning nor empirical evidence supports the axiomatic claims that 'globalization' will promote a convergence toward better environmental practices, or toward worse environmental practices, or instead an growing divergence in environmental practices across countries.

\footnotetext{
* Forthcoming in The Oxford Review of Economic Policy (http://oxrep.oupjournals.org/).
} 
The paper is organized as follows. The next section characterizes globalization as process that has been uneven not only across space but also across institutional spheres. Section 3 distinguishes among four different scenarios of environmental convergence. Section 4 turns to the possibility of environmental polarization, whereby improvements in some places are accompanied by deterioration in others. Section 5 discusses the special subset of environmental problems known as 'global environmental change,' that is, environmental impacts that operate on a global scale. Section 6 briefly addresses a neglected environmental issue - war - in relation to globalization. Section 7 considers the prospects for global environmental governance, and Section 8 offers some concluding remarks.

\section{UNEVEN GLOBALIZATION}

'Globalization', here defined as the integration of economic activities around the world, has long been an uneven process, not only across regions but also across the social spheres that structure economic activity. In general, globalization has proceeded furthest in the sphere of the market - more precisely, in capital and product markets, since labor mobility remains far more constrained by national borders. In the sphere of governance, globalization generally has not proceeded as far. ${ }^{4}$ Geographical disparities in extent of globalization have been well documented (see, for example, Sutcliffe 2004). My focus here is institutional disparities between globalization of the market and globalization of governance, particularly as these affect environmental quality.

Both markets and governance are integral parts of economies. Markets are nested within social institutions that both enable them to function and temper their effects. The rise of capitalism was characterized by what Karl Polanyi (1957 [1944], p. 132) called a 'double movement': the expansion of the market, coupled with the expansion of 'social protection aiming at the conservation of man and nature as well as productive organization.' The latter includes what today we call 'environmental protection' - measures that aim to redress environmental market failures associated with public goods and externalities.

Globalization likewise entails the integration not only of markets, but also of governance, institutions 'capable of resolving conflicts, facilitating cooperation, or, more generally, alleviating collective-action problems in a world of interdependent actors' (Young, 1994, p. 15). The globalization of governance includes formal international agreements such as the 1987 Montreal Protocol, which curtailed the use of chemicals that deplete the Earth's protective ozone layer; supranational institutions such as the European Union, which has recently proposed regulations that will shift onto manufacturers the burden of proof for safety of industrial chemicals released into the environment; ${ }^{5}$ and informal governance by 'global civil society' (Lipschutz and Mayer, 1996; Sonnenfeld and Mol, 2002) and by decentralized 'networks' encompassing both state and non-state actors (Haas, 2003).

When trade occurs at prices that do not capture external costs and external benefits, market integration is accompanied by the globalization of market failure (Boyce, 2002). Yet the absence of corrective policies also represents a governance failure. Institutions of 
governance can fail to redress market failures for reasons of both inability (for example, bureaucratic incompetence) and unwillingness (for example, the political influence of those who would bear the costs of internalization). ${ }^{6}$ The unevenness in the globalization of markets and governance exacerbates the ability side of the problem. As discussed below, it may also create new impediments on the willingness side.

\section{ENVIRONMENTAL CONVERGENCE: FOUR SCENARIOS}

In debates on North-South trade, it is often assumed that production processes in the global South tend to be more environmentally degrading than those in the global North, by virtue of weaker demand for environmental quality (ascribed to low incomes), the weaker ability of governments to promulgate and enforce environmental regulations, or both. Hence trade occurs on a tilted playing field, where Southern producers have a competitive advantage over their Northern counterparts thanks to their greater scope for externalization of costs.

Economic theory is often invoked to maintain that a level playing field - one with no international differences in environmental standards - is not necessarily optimal: the marginal costs and benefits of environmental quality are likely to vary across locations. ${ }^{7}$ Two points should be noted in this connection. First, this does not imply that existing variations in standards across countries are optimal, nor that moves toward greater harmonization would not be welfare-improving in conventional terms. Second, international differences in the 'optimal' level of environmental quality are partly perhaps mainly - attributable to differences in ability to pay: in this sense it is 'efficient' for poorer people to breathe dirtier air. This distribution-blind notion of optimality is unexceptional in neoclassical economics, but its wider normative appeal as a basis for policy is questionable. Elsewhere I have suggested that a rights-based allocation of access to a clean and safe environment - a principle enshrined in dozens of national constitutions around the world - is an attractive alternative to the wealth-based allocation principle founded on willingness to pay. ${ }^{8}$

Here, however, our concern is not normative prescription but rather positive description. As in the NAFTA debate, the question is whether economic integration will lead to 'harmonization upward' in which the South becomes more like the North, or a 'race to the bottom' in which the opposite occurs. These opposing outcomes are labeled 'ecological modernization' and 'environmental protectionism,' respectively, in Figure 1, based on prominent schools of thought that have emphasized these possibilities.

[insert Figure 1 around here]

In principle we can distinguish two further paths of convergence, in which the NorthSouth environmental gradient is reversed: that is, Southern production is cleaner and more sustainable than that of competing sectors in the North. That this is not a purely hypothetical possibility will be illustrated below. In Figure 1, these paths are labeled the 'greening the North' (when the North moves up the gradient, becoming more like the 
South) and 'environmental imperialism' (when the South moves down the gradient to become more like the North).

Of course, these stylized scenarios simplify complex processes. One scenario need not fit all environmental problems; it is quite possible, for example, that in some respects the environmental gradient runs from North to South while in others it runs in the opposite direction. Harmonization may occur not at either end of the spectrum, but rather somewhere in the middle. And in some cases globalization may promote divergence rather than convergence. To begin mapping out the possibilities, this section considers the four convergence scenarios in turn.

\section{(i) Ecological Modernization}

The term 'ecological modernization' was coined in the 1980s by European sociologists to describe recent changes in production and consumption in industrialized countries. In many cases these have reduced use of natural resources and emissions of pollutants per unit output, and in some cases these reductions have been substantial enough to generate net environmental improvements alongside economic growth (see, for example, Weale, 1992 and Spaargaren and Mol, 1992).

Ecological modernization theorists interpret these transformations as a response not only to market signals, but more importantly to the growth of environmental concerns among the public and policy makers. ${ }^{9}$ Although originally put forward as an analysis of trends in industrialized countries, the theory has been extended globally by some of its proponents. In so doing, most have accepted the conventional premise that the environmental-quality gradient runs from North to South. Thus Mol $(2001,157)$ writes of 'the need to harmonize environmental capacities and regimes up to at least the level that has been achieved in the [Europe-North America-Japan] triad countries.'

Mechanisms identified as vehicles for such harmonization upward include income growth, foreign direct investment, international agreements, and 'governance from below':

- A positive effect from income growth is premised on view that globalization leads to rising per capita incomes, and that the latter in turn lead to greater effective demand for environmental quality (often referred to as a better ability to 'afford' a cleaner environment). During the NAFTA debate, for example, Mexican president Carlos Salinas proclaimed, 'Only through widespread prosperity can we have the resources to channel toward the protection of land, air and water' (quoted by Hogenboom, 1998, 180). Both links - from globalization to rising incomes, and from rising incomes a better environment - are open to question. With respect to the latter link, it is important to recognize that many aspects of environmental quality are public goods. To be politically effective, demand for environmental quality therefore must be articulated through institutions that overcome both the free-rider problem and political opposition from the beneficiaries of cost externalization. I return to this issue in the next section. 
- Foreign direct investment is sometimes portrayed as a vehicle for environmental improvement on the grounds that foreign firms have superior technological knowhow, derived from production in countries with stricter regulations, and that they find it efficient to use standardized processes to produce standardized products. In addition, foreign firms may be more sensitive to reputational concerns than local firms, and more subject to media scrutiny and pressure from public opinion. In keeping with this prediction, some empirical studies have found evidence of 'pollution halos' - above-average environmental performance - associated with foreign investment. In a review of this literature, Zarsky $(1999,14)$ concludes that the evidence is mixed, and that 'the most significant determinant of firm performance is community pressure' rather than the origin of investment per se. ${ }^{10}$

- International agreements can also promote upward harmonization in environmental practices. Examples of such agreements include the treaties on oceanic pollution, transport of hazardous waste, and ozone-depleting chemicals (see Table 1). Neumayer (2002) finds that the degree of democracy - as measured by indices of political rights and 'voice and accountability' - is a strong predictor of whether countries will enter into environmental agreements, again pointing to the importance of political variables in determining outcomes.

[insert Table 1 around here]

- 'Governance from below' refers to de facto rules that are imposed not by governments, but by 'civil society' and public opinion. A series of studies at the World Bank, for example, has found that 'informal regulation' by local communities can limit industrial pollution even in the absence of formal regulation (see Pargal and Wheeler, 1996; Pargal et al., 1997). These studies generally find average income and education of communities to be strongly correlated with successful informal regulation. Transnational environmental alliances also can increase the bargaining power of local communities (see, for example, Keenan, de Echave, and Traynor, 2003). In addition to directly influencing the decisions of private firms and government officials, informal actors have developed third-party certification and 'eco-labeling' initiatives that respond to and influence consumer demands. ${ }^{11}$

\section{(ii) Environmental Protectionism}

Instead of harmonization upward, many environmentalists maintain that globalization promotes a 'race to the bottom,' in which competition for private investment undermines environmental regulation. In its weaker variant, this argument holds that global competition impedes new regulation so that South countries remain 'stuck at the bottom' (Porter, 1999) and Northern countries are 'stuck in the mud' (Zarsky, 1997). In its stronger variant, globalization spurs the competitive lowering of standards in the North, ultimately leading to convergence on the lowest common denominator. Hence the claim in the NAFTA debate that the trade agreement would 'sabotage' U.S. environmental laws. $^{12}$ 
The usual policy recommendation flowing from this analysis is that Northern countries should use compensating tariffs or other trade restrictions to prevent 'ecological dumping' - the sale of products at prices below their marginal social cost of production by virtue of externalization of environmental costs. ${ }^{13}$ Hence this school of thought is here termed 'environmental protectionism.'

The logic rests on the uneven globalization of markets and governance:

International trade increases competition, and competition reduces costs. But competition can reduce costs in two ways: by increasing efficiency or by lowering standards. A firm can save money by lowering its standards for pollution control, worker safety, wages, health care and so on - all choices that externalize some of its costs... Nations maintain large legal, administrative and auditing structures that bar reductions in the social and environmental standards of domestic industries. There are no analogous international bodies of law and administration; there are only national laws, which differ widely. Consequently, free international trade encourages industries to shift their production activities to the countries that have the lowest standards of cost internalization - hardly a move toward global efficiency. (Daly, 1993, 52).

Empirical studies generally have concluded that environmental regulation does not, in fact, have much effect on firms' competitiveness (for a review, see Jaffe et al., 1995). At the same time, however, studies of 'revealed comparative advantage' in pollutionintensive industries (such as pulp and paper, mining, chemicals, and petroleum products) have found that countries in the global South and eastern Europe account for a rising share of world exports. ${ }^{14}$ This relocation of 'dirty industries' - a policy infamously recommended by the World Bank's chief economist in the early 1990s (The Economist, 1992) - occurs mainly via net additions to the capital stock, given sunk costs in existing Northern facilities.

Even if there were robust evidence that dirty industries are migrating from North to South, this would not automatically put downward pressure on environmental standards in the North, as envisaged in the strong variant of the race-to-the-bottom logic. It is conceivable that instead Northern countries would allow, or even encourage, the displacement of environmental costs to the South, with international trade allowing them to import raw materials, intermediate inputs, and final products at prices held down by cost externalization. ${ }^{15}$ In other words, the North could maintain higher environmental standards domestically, while reaping 'ecological subsidies' from the South. I return to this possibility in section 4 .

\section{(iii) Greening the North}

I now turn to scenarios where the environmental-quality gradient runs from South to North - that is, where Southern production is cleaner and more sustainable than competing production in the North. At first blush this may seem implausible, given the 
deeply ingrained assumption that environmental quality is a luxury that only the affluent can afford, or at least a normal good for which demand rises with income. Indeed it is often assumed that the 'bottom billion' - the world's poorest people - 'cause a disproportionate share of environmental degradation' (Myers 1993, 23).

This demand-driven model neglects the supply side of environmental quality. We know that the global North's share of world income - and hence of world production and consumption - far exceeds that of the global South. In the year 2000, those countries with the richest $20 \%$ of the world's population, in terms of per capita incomes, accounted for 67 times as much income as the countries with the poorest $20 \%$. The ratio narrows when computed on the basis of purchasing-power parity (PPP), but even then the average income of the richest quintile exceeded that of the poorest quintile by a ratio of sixteen to one (Sutcliffe, 2003, 10).

Environmental degradation per unit income may vary across countries or income classes. If degradation were sufficiently concave in income, the poorest quintile in theory could generate more environmental degradation than the richest quintile. But merely to equal the degradation generated by the top quintile, the environmental degradation per unit PPP-adjusted income in the bottom quintile would have to be sixteen times greater. Such a disparity seems improbable. In some respects, at least, environmental degradation per unit income may even be greater for the rich. Contrast, for example, the pollution generated by automobiles compared to bicycles, the amount of non-renewable resources used to produce a bushel of grain in the United States compared to India, or the pollution generated in the production and disposal of synthetic as opposed to natural fibres.

If there is indeed a gradient along which certain aspects of environmental quality are better in the South than in the North, then an optimistic view of globalization is that it will promote the 'greening of the North' (Sachs et al., 1998). This is akin to the ecological modernization school of thought in that it emphasizes possibilities for harmonization upward, but with the difference that it reverses the relative positions of North and South.

Broadly speaking, there are two routes by which greening of the North could come about. The first is via reductions in Northern consumption levels, a change that could be brought about by either falling incomes or a shift in preferences away from goods in favor of leisure, as advocated by the 'voluntary simplicity' movement in the United States. There is little historical precedent, however, for expecting either to happen on a meaningful scale in the foreseeable future.

The second is via transformations of production and consumption that reduce environmental degradation per unit income. This is sort of change envisioned by the ecological modernization school, but in this scenario it is the North that 'catches up' with the South in terms of environmental practices.

Several recent trends in agriculture in the industrialized countries illustrate this possibility. In the United States, for example, organically grown products are now the fastest-growing segment of the food market, with sales rising at more than $20 \%$ annually in the past decade 
(Dimitri and Greene, 2002). Urban agriculture and community-supported agriculture have also grown substantially, and even when these are not 'organic' (in the sense of zero use of agrochemicals), they minimize negative externalities in transportation, as well as generating positive externalities in the form of community amenities (Pinderhughes, 2003). On a related front, the 'slow food' movement that originated in Italy in the late 1980s is

promoting the conservation and revival of traditional agricultural practices (Petrini, 2003). ${ }^{16}$ Such 'greening of the North' is by no means a uniform process, however: it has come about partly as a reaction against other features of globalization, such as the use of genetically modified organisms in agriculture and the spread of multinational fast-food restaurant chains.

\section{(iv) Environmental Imperialism}

In the final convergence scenario, globalization undermines relatively clean, sustainable production in the global South. I term this 'environmental imperialism' to evoke the parallel with economic and political subordination of South to North. Here I illustrate this possibility by means of two examples: the displacement of jute by polypropylene, and the displacement of Mexican maize by U.S. maize.

\section{Jute versus polypropylene}

Since the Second World War, international markets for renewable natural raw materials such as cotton, jute, sisal and rubber have faced increasingly tough competition from synthetic substitutes. ${ }^{17}$ The former are produced mainly in the global South, the latter mainly in the global North. While the production of natural raw materials can have substantial negative environmental impacts (as in the case of pesticide-intensive cotton cultivation), in general synthetics entail greater environmental costs. The competition between jute and polypropylene is a case in point.

Jute, traditionally used to produce hessian (burlap) cloth and carpet backing, is the second most important natural fibre in world trade after cotton. In the late 1960s, stimulated by U.S. military orders for sandbags for the Vietnam war, polypropylene began to compete with jute. Between 1970 and 1992, jute imports to North America and western Europe plummeted from 1.0 million to 52,000 metric tons, and jute's real price fell by $70 \%$ (Boyce, 1995). This collapse hit particularly hard at the incomes of small farmers and agricultural laborers in Bangladesh, the world's premier jute exporting country.

The environmental impacts of jute production are modest. Bangladeshi farmers use only modest amounts of chemical fertilizers and little pesticide on the crop. The country's flooded jute fields support diverse fish populations, an important positive externality for rural people. Like all plants, jute sequesters atmospheric carbon, a further positive externality. At the end of the product life cycle, jute biodegrades in the soil.

Polypropylene, jute's main competitor, is manufactured by multinational petrochemical firms. The U.S. is the world's leading producer. Polypropylene production generates emissions of numerous air pollutants, including particulates, sulfur oxides, nitrogen oxides, 
carbon monoxide, volatile organic compounds, and other toxins, in addition to carbon dioxide. Since it is not biodegradable, polypropylene generates further environmental costs in the form of landfill disposal, incineration, or litter at the end of the product life cycle.

The price advantage that has helped polypropylene to displace jute arises in no small measure from the failure of market prices to internalize environmental costs. ${ }^{18}$ The result of the global competition between the two has been the displacement of a relatively 'green' Southern product by a relatively 'brown' Northern product. Even within Bangladesh, plastic shopping bags have begun to replace jute ones.

\section{Maize: Mexico versus the United States}

Maize is the leading crop in both Mexico and the United States. Competition between producers in the two countries has intensified in recent years, as the Mexican government has cut support to small farmers and lowered maize tariffs.

Mexico is the historic center of origin of maize, and the modern center of the genetic diversity in the crop. In the hilly lands of southern and central Mexico, campesino farmers grow thousands of different varieties of maize in small plots that botanists call 'evolutionary gardens' (Wilkes, 1992). On these farms, the maize plant continues to evolve with the assistance of the human hand - in the process Darwin called 'artificial selection' - in response to climate change and newly emerging strains of pests and plant diseases. The campesinos thus provide a valuable positive externality to humankind - the in situ conservation and evolution of genetic diversity in one of our main food crops.

In the United States, fewer than a dozen varieties account for half of total acreage under maize. Only a few hundred varieties, many of them closely related, are commercially available. The crop therefore suffers from genetic vulnerability - the eggs-in-one-basket syndrome - a problem dramatically revealed in 1970 when a new strain of leaf blight destroyed one-fifth of the nation's corn harvest. In the effort to remain a step ahead of evolving pests and pathogens, U.S. plant breeders run a 'varietal relay race,' constantly developing new varieties that incorporate resistance to new threats. The average commercial lifespan of a U.S. corn variety is only seven years. The raw material for this race is the genetic diversity found in the evolutionary gardens of traditional agriculture.

By the measuring stick of the market prices, U.S. farmers are more 'efficient' than their Mexican counterparts. Prior to NAFTA, U.S. maize sold at roughly $\$ 110 /$ ton at the border, whereas Mexican growers received $\$ 240 /$ ton. Several factors contribute to the price advantage of U.S. corn: (i) natural conditions such as better soils, more regular rainfall, and a killing frost that limits pest populations; (ii) farm subsidies that reduce U.S. market prices; (iii) the externalization of environmental costs, such as groundwater contamination by pesticides; and (iv) the failure of market prices to internalize the value of sustaining genetic diversity provided by Mexican farmers. ${ }^{19}$

Since NAFTA went into effect, Mexican imports of U.S. corn have risen from less than one million tonnes/year to more than five million tonnes/year. Meanwhile the price of maize in 
Mexico has fallen by more than $70 \%{ }^{20}$ If these trends persist, they are likely to accelerate genetic erosion - the loss of intra-specific diversity - in the crop. ${ }^{21}$

Some comfort can be taken from the fact that samples of many Mexican maize varieties are stored in 'seed banks' at agricultural research institutes in Mexico and elsewhere. But seed banks are insecure, being subject to the perennial hazards of underfunding, accidents, and war. Most of the maize stored in the world's single largest collection, at the Vavilov Institute in St. Petersburg, today is believed to be non-viable due to inadequate maintenance. Moreover, having seeds 'in the bank' is not the same as knowing about varietal properties such as pest resistance and climate sensitivity, information that is most readily obtained in the field. And even at best, seed banks can conserve only the existing stock of genetic diversity; they cannot replicate the ongoing process of evolution that takes place in the farmers' fields. ${ }^{22}$

As in the case of jute and polypropylene, the competition between Mexican and U.S. maize pits relatively 'green' production in the South against relatively 'brown' production in the North. If we view globalization through a long-term lens, looking back to the era of colonialism and the industrial revolution, this may have been the more common type of race to the environmental bottom.

\section{ENVIRONMENTAL POLARIZATION}

Rather than convergence, globalization instead could promote polarization: widening disparities in environmental quality across countries. The most likely polarization scenario, discussed in this section, would combine environmental improvements in the global North together with increasing environmental degradation in the global South. Regardless of whether a 'green' North and 'brown' South is a good description of the current situation, it could be a prediction of where the world is headed.

The impacts of pollution and natural resource depletion are often concentrated in specific localities. This fact opens possibilities for 'environmental cost shifting' so as to separate those who benefit from an economic activity from those who bear its external costs (Opschoor, 1992, 36). Globalization increases possibilities for environmental cost shifting by widening the spatial distance across which economic interactions take place. It also can widen what can be termed the 'social distance' between the beneficiaries of cost externalization and those who bear these costs, making the latter less able to influence the actions of the former. The likelihood of polarization hinges on whether globalization also promotes countervailing forces, such as the development of global civil-society networks, which offset these effects by reducing social distance.

To frame the discussion, I begin this section with a brief overview of the political economy of environmental degradation. In contrast to the neoclassical treatment of environmental problems as simply a result of missing markets and impersonal governance failures, political economy suggests that the identities of those who gain and lose by virtue of cost externalization help to determine the extent of corrective action 
undertaken by institutions of governance. I then review evidence on the impact of power disparities within countries on the magnitude of environmental degradation. I then turn to the impacts of globalization on prospects for environmental cost shifting.

\section{(i) Political Economy of Environmental Degradation}

Environmentally degrading economic activities generally involve winners who benefit from these activities as well as losers who bear their costs. Without winners, the activities would not occur. Without losers, their environmental impacts would not matter from the standpoint of human well-being.

In analyzing the dynamics of environmental degradation, we therefore can ask why it is that the winners are able to impose environmental costs on the losers. When market failures take the form of environmental externalities, why do the institutions of governance fail to remedy them? There are three possible reasons:

- First, the losers may belong to future generations who are not here to defend themselves. In such cases, the only remedy for governance failure is a social commitment to an ethic of intergenerational responsibility.

- Second, the losers may lack adequate information as to the extent or sources of environmental burdens. It is often difficult, for example, to link health problems to pollution, and to track pollution to its source. In such cases, environmental education and right-to-know legislation are crucial elements of a solution.

- Third, the losers may lack sufficient power to alter the behavior of the winners. In such cases, a change in the balance of power between winners and losers is a necessary condition for greater environmental protection.

Here I focus on the third explanation - power disparities - since this is most directly affected by globalization.

In the past two decades, a growing body of literature has documented the uneven distribution of environmental burdens within countries, and their correlation with disparities in political power. In the United States, studies of 'environmental justice' have shown that communities with lower incomes and higher percentages of racial and ethnic minorities tend to face disproportionate environmental hazards. ${ }^{23}$ For example, even when controlling for income, Ash and Fetter (2002) find that African-Americans tend to reside not only in metropolitan areas with above-average levels of point-source air pollution, but also in localities that have higher-than-average pollution levels for the metropolitan area.

In their analysis of informal regulation in Indonesia, Pargal and Wheeler (1996) similarly find that communities with lower average incomes and educational attainments tend to have higher levels of industrial water pollution, even after controlling for other variables such as the volume of output and the age of nearby factories. They attribute this to 
differences in the 'implicit price' of pollution, which they define as 'the expected penalty or compensation exacted by the affected community.' Following this logic, Hettige et al. $(2000,452)$ write that 'cost-minimizing firms with flexible abatement choices will control pollution to the point where their marginal abatement costs equal the "price" exacted for pollution by the affected parties.' The latter may include local communities, government officials, non-governmental organizations, stockholders, and consumers - all parties who are 'in a position to impose some cost on a firm or plant if its emissions exceed the norms adopted by that group.' The resulting 'price' of pollution varies across localities.

Pollutees (those who bear costs from environmental degradation) can influence the decisions of polluters in two broad ways. The first is when their well-being enters directly into the polluters' utility function. This can be termed internalization through sympathy. Following Sen $(1975,23)$, we can represent the degree of sympathy by means of a parameter, $h$, that indicates the weight placed on the well-being of others relative to one's own well-being. When $h_{i}=0$, the polluter is indifferent to the well-being of the $i^{\text {th }}$ individual. When $h_{i}=1$, the polluter values impacts on the $i^{\text {th }}$ individual the same as impacts on oneself. If $h_{i}=1$ for all $i$ individuals impacted by pollution, there is full internalization.

The second way pollutees can influence the decisions of polluters is through the political process. This can be termed internalization through governance, with governance understood to encompass both formal or informal rules that constrain behavior. Like sympathy, the ability of pollutees to use governance to alter the behavior of polluters is a matter of degree. Let the parameter $\pi_{i}$ to represent the power of the $i^{\text {th }}$ individual to affect social decisions regarding pollution. Where $\pi_{i}=0$ for all pollutees, the 'price' of pollution (set implicitly by informal regulation or formal standards, or explicitly by pollution taxes or tradable permits) is likewise zero.

More generally, we can describe environmental governance outcomes as following a power-weighted social decision rule (Boyce 2002, chs. 4-6):

$$
\max \sum_{i} \pi_{i} b_{i}
$$

where $b_{i}=$ the net benefit that individual $i$ derives from an environmentally degrading activity (net cost if $b_{i}<0$ ). ${ }^{24}$ Where the power of those who benefit - as producers via higher incomes, or as consumers via lower prices - exceeds the power of those who bear net costs, the social decision rule leads to weaker environmental governance than when the reverse is true. In general, the social decision rule yields outcomes that are 'efficient' in the conventional cost-benefit sense only in the special case where $\pi_{i}$ is the same for everyone.

The social distance between the winners and the losers affects both types of internalization. As Princen (1997, 235) observes, the obscuring of environmental costs and their displacement onto others 'impede ecological and social feedback and create 
cognitive, institutional, and ethical lags between initial benefits and eventual full costs.' When those who benefit from polluting activities do not have any social ties to those who bear the costs - when they do not know them, or see them, or perhaps even know that they exist - there is little scope for internalization through sympathy. When the winners are very powerful relative to the losers, the scope for internalization through governance is correspondingly limited.

\section{(ii) Power Disparities and the Environment}

The power-weighted social decision rule generates two testable hypotheses. The first is that the distribution of environmental burdens is correlated with power-related variables such as income, education, race, and ethnicity. Communities whose residents are poorer, less educated, or belong to historically marginalized racial and ethnic groups will tend to bear greater burdens that communities whose residents are affluent, well-educated, or belong to historically dominant racial and ethnic groups.

As noted above, a substantial empirical literature has emerged on this topic. In general, its findings are broadly consistent with this hypothesis. There is room for debate, as always, regarding causal explanations for observed correlations. Some researchers have suggested, for example, that the inverse relation between average incomes and toxic hazards often found by studies in the U.S. may arise not from disproportionate siting of hazardous facilities near low-income neighborhoods, but rather from market dynamics in which low-income people are drawn to these locations by lower property values. ${ }^{25}$ This logic is would have to be stretched, however, to explain correlations between hazards and race that persist even after controlling for income. ${ }^{26}$

The second hypothesis is that societies with wider power disparities tend to have more environmental degradation. That is, power disparities affect the magnitude of pollution and resource depletion, as well as their distributional incidence. This hypothesis is based on the assumption that there is a positive correlation between net benefits $\left(b_{i}\right)$ and power $\left(\pi_{i}\right)$, an assumption that seems reasonable in that both are likely to be correlated with wealth. $^{27}$

Empirical studies of this second hypothesis remain scarce, but support for it can be drawn from several recent cross-country studies that have investigated the impact of political variables on environmental performance. These studies were sparked by research suggesting that environmental degradation - or at least some types of it - is concave in income, and that high-income countries have passed a turning point beyond which further income gains are associated with environmental improvements. In an early example, the World Bank $(1992,41)$ reported an inverted U-shaped relationship of this type between atmospheric sulfur-dioxide and per capita income.

This relationship has been dubbed the 'environmental Kuznets curve' (EKC), due to its likeness to the original Kuznets curve depicting a relationship between income inequality and per capita income (see Figure 2). As in the case of its namesake, the EKC has sometimes been taken to imply that problems that accompany economic growth will be 
resolved, more or less automatically, by growth itself. Thus Beckerman (1992) writes, 'in the end the best - and probably the only - way to attain a decent environment in most countries is to become rich.'

[insert Figure 2 around here]

Notwithstanding the allusion to Kuznets' earlier work on income inequality, few studies of the EKC have examined the relationship between environmental quality and inequalities of income, wealth, or power. Yet combining the two inverted-U curves (and assuming that the income levels at which they reach their turning points are roughly comparable), we can infer a positive correlation between environmental degradation and income inequality, as depicted in Figure 2. Such a correlation does not prove causation, of course, but it is intriguing. And because the curves themselves (when found to exist at all) are statistical relationships, rather than iron laws, there are many outliers - for example, countries with relatively low income inequality and low per capita income making it possible to attempt to distinguish econometrically between the environmental impacts of income and inequality.

To investigate the impacts of power disparities on environmental quality, Torras and Boyce (1998) analyzed cross-country variations in air pollution (ambient concentrations of sulfur dioxide, smoke, and heavy particles), water pollution (concentrations of dissolved oxygen and fecal coliform), and the percentages of the population with access to safe water and sanitation facilities. In addition to per capita income and the Gini ratio of income distribution, their analysis included two other explanatory variables - adult literacy and an index of political rights and civil liberties - regarded as relevant to the distribution of power. In low-income countries, the estimated coefficients on the rights and literacy variables had the expected signs in all cases: higher literacy and greater rights were associated with better environmental quality. These coefficients were statistically significant in the majority of cases. Controlling for these other variables, the estimated effects of income inequality were inconsistent, and the authors suggest that either rights and literacy capture more important aspects of power disparities or the quality of the income distribution data is poor (or both). ${ }^{28}$ They obtain weaker results for the high-income countries, suggesting that rights and literacy are most important when average incomes are low.

Other cross-country studies have also suggested that political rights can be an important determinant of environmental outcomes. Scruggs (1998) found greater rights to have a statistically significant favorable effect on sulfur dioxide concentrations, favorable but weaker effects on particulates and fecal coliform pollution, and an adverse effect on dissolved oxygen. Barrett and Graddy (2000) found air pollution by sulfur dioxide, smoke, and particulates to be 'monotonically decreasing in the extent of democratic freedoms;' for water pollutants, they found statistically significant favorable effects in the cases of fecal coliform, arsenic, and lead. Harbaugh et al. (2000) also found a strong statistical relationship between an index representing democratic participation in government and atmospheric concentrations of sulfur dioxide, smoke, and particulates. 
Further empirical support for the hypothesis that power disparities have an adverse impact on environmental quality comes from a cross-sectional study of the 50 U.S. states by Boyce et al. (1999). The authors derived a power-distribution index from state-level data on voter participation, tax fairness, access to health care, and educational attainment. In a recursive econometric model, they found that states with more equitable distributions of power had stronger environmental policies, and that these in turn were associated with better environmental quality.

\section{(iii) Globalization and Environmental Cost-Shifting}

As globalization extends the arena for environmental cost shifting, the profound inequalities in the worldwide distribution of power and wealth become more relevant to the political economy of environmental degradation. As Sutcliffe $(2003,2004)$ observes, income inequality at the global level exceeds that at the national level even in the most unequal of countries, such as Brazil and South Africa (with the possible exception of Namibia). This is hardly surprising, since a global measure of inequality puts the richest strata of the population in the global North in the same universe as the poorest strata of the global South. The 'power equivalents' of this income distribution - a phrase coined by Kuznets $(1963,49)$ - may likewise be more unequal globally than at the national level. If so, the foregoing analysis suggests that globalization may lead both to environmental polarization between North and South and to an increase in the total magnitude of environmental degradation worldwide.

Having widened environmentally relevant disparities by putting the global rich and the global poor into the same basket, globalization eventually may reduce these disparities by promoting faster growth in the incomes of the poor than of the rich. But the evidence for such a trend is mixed at best. ${ }^{29}$ More promising, perhaps, is the possibility of social developments - the other side of Polanyi's 'double movement' - that increase the political effectiveness of demand for environmental protection in low-income countries. Here too, however, the record to date is not terribly encouraging. While Weidner and Jänicke $(2002,440)$ find some evidence of a global convergence between North and South in environmental policies, at the same time they conclude that capacities for policy implementation have become more unequal, resulting in 'convergence of policies but divergence of outcomes.'

But countervailing forces are set in motion by globalization, too. Advances in telecommunications can shrink social distances, increasing the scope for internalization through sympathy by giving faces and voices to the people who bear environmental costs, and at the same time giving the latter greater access to information and the power that comes with it. Alliances across national boundaries, among local communities, nongovernmental organizations (NGOs), workers, shareholders, and consumers, can alter balances of power. And as discussed in the next section, the phenomenon of global environmental change - where there is little or no scope for cost shifting - may not only give impetus to global environmental governance but also create new opportunities for globally egalitarian politics. 
To illustrate these opposing forces, consider the rapid growth of industrial shrimp farming in the coastal areas of tropical countries. This has been accompanied by the widespread and often violent appropriation of land and aquatic resources from local residents, and by adverse environmental impacts on local communities, spurring polarization (Stonich and Vandergeest, 2001). At the same time, however, the spread of shrimp farms has sparked international alliances of environmental and peasant-based NGOs that defend and reassert community rights to natural assets (Stonich and Bailey, 2000). Similarly, export markets for beef, timber, and minerals have been a major stimulus to Amazonian deforestation. Again, international alliances have emerged to support local people who traditionally have relied on the forest for their livelihoods. These were instrumental in the creation of extractive reserves in Brazil, where local communities have secured their right to harvest latex and other forest products while preventing forest clearing (Hall, 1997). As these examples suggest, globalization not only poses risks of environmental polarization and increased environmental degradation, but also creates opportunities for countervailing forces.

\section{GLOBAL ENVIRONMENTAL CHANGE}

The phrase 'global environmental change' refers to environmental problems like climate change, ozone-layer depletion, and the loss of biodiversity whose impacts are global in scope rather than confined to particular localities. This is the counterpart, in the environmental sphere, to global integration in the spheres of the market and governance: in global environmental change we see integration of the consequences of market and governance failures. Insofar as all countries share in its costs and stand to benefit from remedial actions, global environmental change would seem to be a force for environmental convergence. But in practice, here too there are some polarizing tendencies, due to disparate impacts across locations and disparities in the extent of governance responses.

Disparate impacts arise not only from the greater vulnerability of poorer populations, but also, in some cases, from circumstantial factors. In the case of global warming, for example, the Intergovernmental Panel on Climate Change (IPCC) predicts that average surface temperatures on Earth will rise by $1^{\circ}$ to $4^{\circ} \mathrm{C}$ in this century. Even if adverse impacts were distributed equally across humankind, the poor would suffer most by virtue of the fact that they start from a lower economic base. In addition, climate scientists forecast that the hardest-hit places will include parts of Africa, where droughts are expected to worsen in frequency and intensity, and low-lying regions of tropical Asia prone to increased flooding and cyclones. 'The effects of climate change,' the IPCC $(2001,8)$ concludes, 'are expected to be greatest in developing countries in terms of loss of life and relative effects on investment and the economy.'

These disparate impact are compounded by disparities in the extent of remedial actions. Even if international policies to protect the global environment were guided solely by considerations of 'efficiency,' completely insulated from the impacts of political influence, disparities in remedial actions would arise from the application of conventional 
valuation principles that place equal weight on monetary costs and benefits no matter whether those to whom they accrue are rich or poor. The willingness of the rich to pay for environmental quality, and for goods and services whose production, consumption, and disposal cause environmental degradation, generally exceeds that of the poor by virtue of their greater ability to pay. Hence in the shadow markets of benefit-cost analysis, as in real markets, the 'benefits' of emitting carbon dioxide by driving automobiles on American and European highways may outweigh the costs of drought in Africa or inundations in Bangladesh. This wealth-based principle for efficient resource allocation can be contrasted to a rights-based approach founded on the premise that all individuals have an equal entitlement to a clean and safe environment (Boyce, 2002, Ch. 2).

In practice, efficiency is not the sole criterion guiding social decisions, including decisions to invest in mitigation and adaptation to global environmental change. Political influences also play a role, promoting action on some issues and inaction on others. Consider the contrast in the international responses to ozone-layer depletion and global warming. The 1987 Montreal Protocol on ozone-depleting substances successfully instituted a worldwide phase-out of the use chlorofluorocarbons (CFCs). Although the benefits of CFC use - in refrigeration, air conditioning, fire extinguishers, solvents, foams and aerosols - were concentrated in the industrialized countries, so were the environmental costs. Ozone-layer thinning is most pronounced at the higher latitudes, and light-skinned people are most susceptible to skin cancers and melanomas caused by increased ultraviolet radiation.

This may help to explain why efforts of the scientific community to draw attention to the risks of ozone-layer depletion met with such success. The United States, along with Canada and the Scandinavian countries, took a leading role in international negotiations to curb CFC emissions. Despite scientific uncertainties over the precise mechanisms of ozone-layer depletion, the U.S. administration under President Ronald Reagan took the position that 'in the real world of imperfect knowledge and uncertainty, we, as policymakers, nevertheless have the responsibility to take prudent actions for the benefits of generations yet to come. ${ }^{, 30}$ A contrary suggestion by Reagan's Secretary of the Interior, who urged Americans to adopt a 'personal protection campaign' of wearing sunscreen, long-sleeved shirts, and dark glasses, met with ridicule (Haas, 1992, 218).

This experience can be contrasted with the faltering progress of international efforts to curb global warming by limiting emissions of carbon dioxide from burning fossil fuels. The 1997 Kyoto Protocol sought to cap the carbon dioxide emissions of industrialized countries at roughly $94 \%$ of their 1990 levels $^{31}$ - a modest target compared to the CFC phase out - leaving the emissions of developing countries to be negotiated later. In March 2001 the U.S. administration of President George W. Bush rejected this accord, maintaining that the scientific evidence on climate change remains 'unsettled' and that the treaty is 'fatally flawed' because it would impose costs on the U.S. economy while not setting emissions ceilings for developing countries. As atmospheric carbon dioxide levels continue to rise, the focus of international negotiations is shifting from prevention to adaptation. ${ }^{32}$ This shift increases the likelihood of outcomes that differ across 
countries, reflecting differences in their ability to pay for measures to adapt to climate change.

A crucial issue in international climate negotiations is the allocation of property rights to the carbon-absorptive capacity of the Earth's atmosphere. This presents both a stumbling block and an opportunity. The principle of allocations pegged to historic emission levels, which was applied to industrialized countries in the Kyoto agreement, effectively 'grandfathers' these rights on the basis of past appropriation. This formula is naturally unacceptable to the developing countries, whose emissions per capita remain an order of magnitude below those in the industrialized countries. ${ }^{33}$ An alternative principle would be to allocate rights on the basis of equal per capita entitlements, an idea first proposed by Southern environmentalists (Agarwal and Narain, 1991), and more recently endorsed by Northern scientists on both normative and practical grounds (Baer et al., 2000). ${ }^{34}$ Failure to resolve this issue is one of the reasons given by the Bush administration for its rejection of the Kyoto accord, as noted above. At the same time, a egalitarian resolution would make global environmental governance and instrument for reducing North-South disparities.

\section{WAR AND THE ENVIRONMENT}

In the modern era, war has been a major cause of environmental degradation. This differs from 'normal' environmental degradation in that it is often an objective, rather than a side-effect of the pursuit of other goals. The aim is to make the environment inhospitable or fatal to the enemy. Rather than a cost external to the war-maker's calculus, environmental degradation is seen as an internal benefit.

Examples of such deliberate environmental degradation include the application of herbicides by the U.S. military to defoliate Vietnam (SIPRI, 1976); the Soviet military's systematic destruction of orchards, irrigation infrastructure, and agricultural ecosystems in Afghanistan (Swedish Committee for Afghanistan, 1988); and, most starkly, the dropping of nuclear bombs on the Japanese cities of Hiroshima and Nagasaki in 1945.

An assessment of globalization's environmental impacts would be incomplete without consideration of impacts related to war. Globalization can affect the extent of war-related environmental degradation in two ways: first, by facilitating or restricting access to environmentally destructive weaponry such as landmines, nuclear devices, and other weapons of mass destruction; and second, by exacerbating or easing tensions within and between countries that can precipitate violent conflict. The first affects abilities to degrade the environment for military purposes; the second affects willingness to do so.

The proliferation of landmines illustrates the spread of environmentally destructive weaponry. Today roughly 60 million landmines are embedded around the world; in the most heavily mined countries, like Cambodia, there are more than 100 landmines per square mile. ${ }^{35}$ Efforts to curtail their production, use, and transfer - efforts in which the non-governmental International Campaign to Ban Landmines played a leading role - 
culminated in the 1997 Mine Ban Treaty. ${ }^{36}$ The spread of weapons of mass destruction similarly has been constrained, though not entirely prevented, by the Nuclear Test Ban Treaty of 1962 and the Biological and Toxic Weapons Treaty of 1972, agreements that can be counted among the world's most important international environmental accords. Here again we see a 'double movement' in globalization in the interplay between weapons proliferation and counter-proliferation initiatives.

Globalization can exacerbate risks of violent conflict in several ways: (i) by deepening inequalities of income, wealth, and power, including 'horizontal inequalities' across ethnic, regional, and religious lines (Stewart, 2002); (ii) by facilitating the spread of new norms and aspirations that undermine the legitimacy of pre-existing inequalities (Bardhan, 1997); (iii) by expanding markets for 'lootable' resources, such as diamonds and oil, that can provide both a motive and the means for conflict (Collier and Hoeffler, 2002); and (iv) by triggering 'fundamentalist' reactions against the values (or perceived lack of them) of mass consumer culture. At the same time, there are countervailing efforts of the United Nations and other international institutions to prevent and resolve conflicts and to support 'postconflict' peacebuilding. ${ }^{37}$

The net impact of globalization's effects on the ability and willingness to degrade the environment through war cannot be asserted a priori. It will depend on the actions (or inaction) of governments, international institutions, and civil society. Possible outcomes include both 'harmonization upward' or a 'race to the bottom' on the war-to-peace spectrum. The dominant trend since the Second World War has been polarization rather than convergence: war and the attendant environmental destruction have been concentrated in the global South - especially, in recent times, in sub-Saharan Africa largely bypassing the North. Once again, this can be attributed to disparities both in circumstances and in the extent of remedial efforts.

\section{PROSPECTS FOR GLOBAL ENVIRONMENTAL GOVERNANCE}

In the final analysis, the environmental impact of globalization will hinge, above all, on how our institutions of governance develop as world markets become increasingly integrated. This section considers briefly the prospects for global environmental governance by both formal and informal means. ${ }^{38}$

\section{(i) Formal Governance: Three Avenues}

In the development of formal institutions for global environmental governance, three broad avenues can be distinguished:

- Creation of a World Environment Organization: One possible avenue would be to establish of a new international institution specifically charged with environmental protection, empowered to set and enforce environmental policies. This has been suggested by various authors (see, for example, Esty 1994, and Opschoor 2001), based on the same logic that led to the establishment of 
ministries and agencies for environmental protection at the national level. Arguing that 'environmental externalities should be tackled at their source, which is usually at the point of production, and occasionally at the point of consumption, but rarely at the point of exchange' Griffin $(2003,798)$ observes that international efforts to protect whales have proceeded not by prohibiting trade in whale products, but through a ban on whale harvests enforced by the International Whaling Commission. However desirable in theory, there appears to be little prospect that an effective world environmental organization will be established anytime soon. Among actually existing institutions, the closest thing to such an entity is the Nairobi-based United Nations Environment Programme, whose mandate today is strictly limited to provision of information and assistance.

- Issue-specific international environmental agreements: In the absence of a global institution empowered to carry out regulatory functions, the international community has addressed specific environmental threats - from nuclear proliferation to global warming - by means of issue-specific agreements and treaties. A list of major international environmental agreements to date is presented in Table 1. While the importance of these agreements is evident, so far they have been confined to two subsets of environmental issues: global environmental change and military-related environmental damage. 'Normal' (national-level and local-level) problems of pollution and natural resource depletion have been largely ignored, despite the fact that these are often affected by global economic integration.

- 'Greening' international institutions: A third avenue takes the form of efforts to 'green' international institutions that are dedicated to other objectives, so as to bring environmental considerations into their decision-making processes. Environmental impact assessments are now a standard (if at times superficial) element of project appraisal at the multilateral development banks. While skeptics maintain that such efforts 'will never bring environmental interests on a par with economic interests' (Mol, 2001, 219), it is not evident that the obstacles are any less tractable than those to the creation of a world environment organization or new international treaties. Indeed, the rationale for credit-allocation institutions and policies is precisely to account for externalities and channel financial resources to socially desirable uses. There is no intrinsic reason why international financial institutions should not allocate credit to advance environmental goals (D'Arista and Boyce, 2002). Nor is there any inherent reason why trade agreements must rule out consideration of environmental impacts arising from production and process methods. In the end, these are political choices.

\section{(ii) Informal Governance: Third-Party Certification as an Example}

As discussed above, informal governance can also have important effects on environmental performance. One example, at the global level, is the advent of third-party certification systems that provide information to consumers and stimulate market-based pressures for improved production and process methods. 
Perhaps the best-known case is the timber products certification program of the Forest Stewardship Council (FSC), a non-governmental organization founded in Toronto in 1993. By mid-2001, 25 million hectares of forests - roughly five percent of working forests (i.e., those not set aside in protected areas) worldwide - were certified under FSC environmental and social standards (Conroy, 2001, 6). Demand for FSC-certified products has been augmented by campaigns by environmental organizations to persuade large-volume retail firms to purchase only certified timber when it is available.

This informal governance system emerged in the wake of failed efforts to create an officially-sponsored certification system through the International Tropical Timber Organization. This created a vacuum into which non-governmental organizations moved (Gale, 2002, 279). The result has much in common with formal governance:

Environmental certification programs have most of the same basic organizational elements of legal systems. What they generally lack is a command from a sovereign... Firms subscribe to them because they determine that it is in their interest to do so. Yet it is increasingly common to describe environmental certification as a 'de facto requirement' for doing business in many jurisdictions. When interviewed, corporate officials often state that they feel they have 'no real choice' but to become environmentally certified. (Meidinger, 2001, 10166)

Indeed there are a variety of ways in which informal governance through third-party certification can be incorporated into formal legal systems; for example, by providing incentives via government purchasing or regulatory requirements to firms that meet certification criteria. $^{39}$

(iii) Interaction between Formal and Informal Governance: The Example of 'Rightto-Know' Laws

More generally, formal and informal governance do not operate in isolation from each other. Formal regulation often emerges in response to pressures from civil society, and the scope for informal governance can be increased (or decreased) by formal regulation. 'Right-to-know' laws - formal regulations that compel private firms to furnish environmental information to the public - are a good illustration.

Globalization was the midwife at the birth of the most important environmental right-toknow legislation in the United States: the Emergency Planning and Community Right-toKnow Act of 1986 (EPCRA), which provides the legal basis for the Toxics Release Inventory and other disclosure requirements administered by the U.S. Environmental Protection Agency (Bouwes et al., 2003). The 1984 chemical disaster in Bhopal, India, at a plant owned by the U.S.-based Union Carbide corporation, which led to thousands of deaths and injuries, was the key impetus for EPCRA's passage. There is evidence that EPCRA-mandated public disclosure of deliberate and accidental releases of toxic chemicals has led to reductions in toxic releases. ${ }^{40}$ In effect, such right-to-know laws alter the balance of power between polluters and pollutees. As Weidner and Jänicke (2002, 
432) put it, 'The creation of transparency modifies the power structure in favor of environmental proponents.' Translating this into the terminology of neoclassical economics, such laws can be said to reduce a market imperfection (imperfect information) that impedes Coasian bargaining (Tietenberg and Wheeler, 2000).

EPCRA's geographical reach is limited to the United States. It does not require U.S.based corporations to disclose toxic releases elsewhere - in Bhopal, for example. The International Right-to-Know Campaign, launched in 2003 by a coalition of U.S. environmental, labor, and human rights groups, is attempting to redress this asymmetry by calling for new legislation that would compel U.S.-based corporations to disclose information about their environmental and labor practices overseas. ${ }^{41}$ In a kindred initiative, the 'Publish What You Pay' campaign launched in 2002 by an international coalition of non-governmental organizations, with backing from the financier George Soros, is calling for legislation to require corporate disclosure of payments made to governments for access to natural resources (Soros, 2002). ${ }^{42}$ Both these efforts illustrate how interactions between formal and informal institutions can advance the globalization of environmental governance.

\section{CONCLUDING REMARKS}

This essay has viewed globalization as a process of economic integration that embraces governance as well as markets. In principle, the globalization of governance can counter adverse environmental impacts arising from the globalization of market failure that accompanies the integration of world markets. But there is nothing automatic about this 'double movement' - it rests on human agency, and on balances of power between those who stand to gain and lose from environmental governance.

In assessing the effects of globalization, my main focus has been its impacts on environmental quality in the global North and global South. Closely related to this, however, is a concern with impacts on human well-being. Environmentalists tend to conflate the two, seeing current and future human well-being as dependent on environmental quality. Economists tend to emphasize the tradeoffs that can and do arise between environmental quality and the satisfaction of other human needs and wants. Such tradeoffs pose the positive question of how they are made in practice, as well as the normative question of how they ought to be made. I have suggested above that both questions are intimately bound up with the issue of interpersonal tradeoffs in the wellbeing of different people.

With respect to the positive question of how societies choose to make tradeoffs, I have suggested that these are guided by a power-weighted social decision rule, in which benefits and costs are weighed by the power of those to whom they accrue. This leads to the hypotheses that power disparities affect the distributional incidence of environmental degradation and its overall magnitude ${ }^{43}$ As noted, there is a growing body of empirical literature that has reported findings consistent with these hypotheses. 
With respect to the normative question of how societies ought to make tradeoffs, I have noted the important difference between the wealth-based approach used in conventional cost-benefit analysis, in which values are conditioned by ability and willingness to pay, and a rights-based approach in which all individuals have equal entitlements to a clean and safe environment. As I have discussed at greater length elsewhere, these two approaches can have quite different prescriptive implications. ${ }^{44}$ Under the wealth-based approach, for example, if globalization were to promote environmental polarization, in which improvements in the North were coupled with increasing environmental degradation in the South, this might be argued to be welfare-maximizing; indeed, in the extreme case, pollution imposed on people who have no ability to pay to avoid it is regarded as costless. Under a rights-based approach, environmental costs and benefits are not weighed by the purchasing power of those to whom they accrue. The normative stance that ultimately is adopted by formal and informal institutions for environmental governance will have profound implications for how globalization affects both the distribution of power and access to environmental quality.

This essay has questioned several tenets of conventional thinking about the environmental impacts of globalization. I have argued that the assumption that production practices in the global North are environmentally superior to those in the global South shared by many champions and critics of globalization alike - can be quite misleading, and can lead to the neglect of important environmental issues. I have maintained that globalization can promote environmental convergence via 'harmonization upward,' as argued by its proponents, and via a 'race to the bottom,' as argued by its opponents, but that neither outcome is assured on a priori grounds. I have also noted that instead of convergence, globalization could foster environmental polarization - 'greening' the North and 'browning' the South. Whether this occurs will depend on the extent to which those who face environmental burdens are able to take advantage of new opportunities to bridge social distances and narrow power disparities, so as to promote internalization through sympathy and governance. Similarly, with respect to global environmental change and war-related environmental degradation, I have suggested that depending on the balance among opposing forces, globalization could promote convergence toward better environmental outcomes or toward worse ones, or North-South polarization.

The environmental impacts of globalization not only remain to be seen; they remain to be determined. The outcome will not be dictated by an inexorable logic. Rather it will depend on how the new opportunities created by the globalization of markets and governance alter balances of power, both within countries and among them. As its critics fear, globalization could accelerate worldwide environmental degradation and deepen environmental inequalities. Yet globalization also gives impetus to countervailing forces that could bring about a greener and less divided world. The history of the future is still to be written. 


\section{ACKNOWLEDGEMENTS}

I am grateful to Michael Conroy, Andrew Glyn, Peter Haas and two anonymous referees for helpful comments on an earlier draft of this paper. The usual disclaimers apply.

\section{NOTES}

${ }^{1}$ Senator John Chafee, quoted in Behr, 1993.

2 'Sabotage of America's Health, Food \& Safety, and Environmental Laws,' advertisement in The Washington Post, 14 December 1992, by the Sierra Club, Greenpeace USA, Friends of the Earth, and others; quoted in Commission for Environmental Cooperation $(1996,29)$.

${ }^{3}$ For discussion, see section 3 below.

${ }^{4}$ There is considerable unevenness within the sphere governance, too. For example, the World Bank and International Monetary Fund, in concert with other official creditors and private banks, have often made capital flows to developing countries conditional on implementation of various economic reforms. Within the sphere of global governance, environmental policy has lagged behind.

${ }^{5}$ For an account of the EU's proposed regulations, see Becker and Lee (2003).

${ }^{6}$ See, for example, Jänicke (1990).

${ }^{7}$ See, for example, Barrett (2000), who also points out that there may be differences between harmonization of emission standards and harmonization of environmental quality standards.

${ }^{8}$ See Boyce (2000), reprinted in Boyce (2002, ch. 2).

${ }^{9}$ Thus Mol (2001, p. 211) writes that economic mechanisms 'will always fall short in fully articulating environmental interests and pushing environmental reforms, if they are not constantly paralleled and propelled by environmental institutions and environmental movements.'

${ }^{10}$ Both community pressure and firm responsiveness may differ when foreign firms outsource to unbranded suppliers. In a study of northern Mexico, [REF NEEDED] found that outsourcing by US firms had adverse environmental impacts.

${ }^{11}$ For examples, see section 7 below.

12 There is an obvious analogy with labor standards; see Singh (2004). Indeed environmental protectionism is sometimes depicted by its critics as a smokescreen for other protectionist interests (see, for example, Bhagwati, 1993).

13 'Ecological dumping' need not be intentional. Rauscher $(1994,825)$ proposes a more restrictive definition: 'a scenario in which environmental standards are tighter in the non-tradables than in the tradables sector.' While this comes closer to notion of dumping as a deliberate instrument of trade policy, it is possible that inter-sectoral disparities in environmental standards are not wholly intentional. In any event, proponents of environmental protectionism are more concerned with the effects of ecological dumping than its causes.

${ }^{14}$ Low and Yeats (1992) found a rising share of pollution-intensive exports from developing countries (particularly in southeast Asia) in the period 1965-1988, albeit from a fairly small base. Extending this 
analysis to the period 1992-2000, Bouvier (2003) finds that this trend has continued, with some eastern European countries also emerging as major exporters.

${ }^{15}$ If this is accompanied by declining terms of trade for environment-intensive products, the result could be both 'environmental improvement and economic growth in the North and environmental deterioration and economic stagnation in the South' (Muradian and Martinez-Alier, 2001, 286).

${ }^{16}$ See also http://www.slowfood.com/.

${ }^{17}$ Maizels $(1992,189 ; 1995,108)$ reports that substitution by synthetics reduced the developed marketeconomy countries' consumption of natural raw materials by $2.9 \%$ per year from $1963-65$ to $1971-73,0.9 \%$ per year from $1971-73$ to $1978-80$, and $1.2 \%$ per year from $1978-80$ to $1984-86$.

${ }^{18}$ For details, see Boyce (1995).

${ }^{19}$ For further discussion, see Boyce (1996).

${ }^{20}$ For accounts of the social impacts in rural Mexico, see Weiner (2002) and Becker (2003).

${ }^{21}$ So far, however, relatively few campesinos appear to have abandoned maize cultivation, in part because of the lack of other economic opportunities; see Ackerman et al. (2003).

${ }^{22}$ For further discussion of the value of in situ (in-the-field) crop genetic diversity, see Brush (2000) and Thrupp (1998).

${ }^{23}$ For literature surveys, see Bullard (1994), Szasz \& Meuser (1997), Bowen (2001), and Pastor (2003).

24 'Power' here plays a role analogous to that of 'influence' in Becker's (1983) model of fiscal policy.

${ }^{25}$ See, for example, Been (1994). In a longitudinal study in southern California, one of the few to examine empirically the siting versus 'move-in' question, Pastor et al. (2001) found strong evidence of disproportionate siting.

${ }^{26}$ See, for example, Bouwes et al. (2003) and Ash and Fetter (2002).

${ }^{27}$ Where $b_{i}$ and $\pi_{i}$ are negatively correlated, the result will be 'too little' environmental degradation, by the usual efficiency standard, rather than too much. For discussion, see Boyce $(2002,37-38,51)$.

${ }^{28}$ For further discussion of the impacts of income inequality on environmental quality, see Boyce (2003).

${ }^{29}$ For reviews of the evidence, see Sutcliffe $(2003,2004)$.

${ }^{30}$ Deputy Assistant Secretary of State Richard Benedick, quoted by Haas $(1992,191)$.

${ }^{31}$ The exact percentages varied somewhat among the industrialized countries.

${ }^{32}$ See Revkin (2002).

${ }^{33}$ Per capita emissions in the U.S. exceed 5 tons of carbon $(\mathrm{tC})$ per year and those of western Europe and Japan are in the 2-5 tC range. The average for developing countries is $0.6 \mathrm{tC} / \mathrm{year}$, with more than 50 countries having emissions of less than $0.2 \mathrm{tC}$ (Baer et al., 2000).

${ }^{34}$ A national-level variant of this principle is the 'sky trust' that would use a cap-and-trade approach to cut emissions, and rebate the revenues to the public via equal per capita dividends (see Barnes, 2001; Barnes and Breslow, 2003). 
${ }^{35}$ UNICEF (1996) reported that Cambodia had 10 million landmines, 143 per square mile. At the time, UN put the total number of embedded landmines worldwide at 110 million; more recent estimates are generally closer to 60 million.

${ }^{36}$ As of October 2003, the treaty had been signed by 141 countries. In addition, nine other countries had signed but not completed the ratification process. Prominent among the 44 countries that have not signed or ratified the treaty are the United States, Russia, and China. For updated information, see the website of the International Campaign to Ban Landmines, http://www.icbl.org/.

${ }^{37}$ See, for example, UN Secretary-General (1992), Carnegie Commission (1997) and World Bank (1998).

${ }^{38}$ For further discussion, see Haas (2002).

${ }^{39}$ In a review of the potential of environmental certification programs to become 'engines of change' in U.S. law, Meidinger $(2001,10176)$ concludes that 'certification programs are natural targets for incorporation by legal systems because they have elements of formality, continuity, and institutionalization.'

${ }^{40}$ For discussions of right-to-know legislation in the United States and its impact on environmental protection, see Rich et al. (1993), Konar and Cohen (1995), Khanna et al. (1998), and Tietenberg and Wheeler (2000).

${ }^{41}$ For information, see http://www.irtk.org/.

${ }^{42}$ For information, see http://www.publishwhatyoupay.org/.

${ }^{43}$ As noted in section 4, the power of those who bear environmental costs relative to those who benefit from cost externalization can also be described in terms of their ability to put an implicit or explicit 'price' on environmental degradation.

${ }^{44}$ See Boyce (2002, chs. 2 and 4). 


\section{REFERENCES}

Ackerman, Frank et al. (2003), 'Free Trade, Corn, and the Environment: Environmental Impacts of US-Mexico Corn Trade Under NAFTA,' Medford, Massachusetts: Tufts University, Global Development and Environment Institute, Working Paper No. 03-06. Available at: http://ase.tufts.edu/gdae/Pubs/wp/03-06-NAFTACorn.PDF.

Agarwal, Anil and Narain, Sunita (1991), Global Warming in an Unequal World: A Case of Environmental Colonialism, New Delhi, Centre for Science and the Environment.

Ash, Michael and Fetter, T. Robert (2002), 'Who Lives on the Wrong Side of the Environmental Tracks? Evidence from the EPA's Risk-Screening Environmental Indicators Model,' Amherst, Massachusetts, Political Economy Research Institute, Working Paper No. 50. Available at: http://www.umass.edu/peri/pdfs/WP50.pdf.

Baer, Paul et al. (2000), 'Equity and Greenhouse Gas Responsibility,' Science, 289(29 September), 2287.

Bardhan, Pranab (1997), 'Method in the Madness? A Political-Economy Analysis of the Ethnic Conflicts in Less Developed Countries,' World Development, 25(9), 1381-1398.

Barnes, Peter (2001), Who Owns the Sky? Our Common Assets and the Future of Capitalism, Washington, D.C., Island Press.

Barnes, Peter and Breslow, Marc (2003), 'The Sky Trust: The Battle for Atmospheric Scarcity Rent,' in James K. Boyce and Barry G. Shelley, eds., Natural Assets:

Democratizing Environmental Ownership, Washington, D.C., Island Press, 135-149.

Barrett, Scott (2000), 'Trade and Environment: Local versus Multilateral Reforms,' Environment and Development Economics, 5, 349-359.

Barrett, Scott and Kathryn Graddy (2000), 'Freedom, Growth, and the Environment,' Environment and Development Economics, 5, 433-456.

Becker, Elizabeth (2003), 'U.S. Corn Subsidies Said to Damage Mexico,' New York Times, 27 August.

Becker, Elizabeth and Lee, Jennifer B. (2003), 'New Trans-Atlantic Trade Dispute: Washington Criticizes Europe's Plan to Regulate Chemicals,' International Herald Tribune, 8 May, p. 1.

Becker, Gary (1983), 'A Theory of Competition Among Pressure Groups for Political Influence,' Quarterly Journal of Economics, 48, 371-400.

Beckerman, Wilfred (1992), 'Economic Growth and the Environment: Whose Growth? Whose Environment? World Development, 20, 481-496. 
Been, Vicki (1994), 'Locally Undesirable Land Uses in Minority Neighborhoods: Disproportionate Siting or Market Dynamics,' Yale Law Journal, 103, 1383-1422.

Behr, Peter (1993), 'Environmental Issues Emerge as Key to Trade Pact on Hill,' Washington Post, 3 March, p. A14.

Bhagwati, Jagdish (1993), 'The Case for Free Trade,' Scientific American, November, pp. 41-49.

Bouvier, Rachel (2003), 'Three Essays on Income, Inequality, and Environmental Degradation,' Ph.D. dissertation, University of Massachusetts-Amherst.

Bouwes, Nicolaas W., Hassur, Steven M., and Shapiro, Marc D. (2003), 'Information for Empowerment: The EPA's Risk-Screening Environmental Indicators Project,' in James K. Boyce and Barry G. Shelley, eds., Natural Assets: Democratizing Environmental Ownership, Washington, D.C., Island Press, 117-134.

Bowen, William M. (2001), Environmental Justice Through Research-Based Decisionmaking, New York, Garland Publishing.

Boyce, James K. (2003), 'Inequality and Environmental Protection,' Amherst, Massachusetts, Political Economy Research Institute, Working Paper No. 52. Available at: http://www.umass.edu/peri/pdfs/WP52.pdf.

Boyce, James K. (2002), The Political Economy of the Environment. Cheltenham: Edward Elgar.

Boyce, James K. (2000), 'Let Them Eat Risk: Wealth, Rights, and Disaster Vulnerability,' Disasters, 24(3), 254-261.

Boyce, James K. (1996), 'Ecological Distribution, Agricultural Trade Liberalization, and In Situ Genetic Diversity,' Journal of Income Distribution, 6(2), 263-284.

Boyce, James K. (1995), 'Jute, Polypropylene, and the Environment: A Study in International Trade and Market Failure,' Bangladesh Development Studies, 23(1 \& 2), 49-66.

Boyce, James K., Klemer, Andrew R., Templet, Paul H. and Willis, Cleve E. (1999), 'Power Distribution, the Environment, and Public Health: A State-Level Analysis,' Ecological Economics, 29, 127-140.

Brush, Stephen B. (2000), 'The Issues of In Situ Conservation of Crop Genetic Resources,' in Stephen B. Brush, ed., Genes in the Field: On-Farm Conservation of Crop Diversity, Boca Raton, Lewis Publishers, 3-26. 
Bullard, Robert D., ed. (1994), Unequal Protection: Environmental Justice and Communities of Color, San Francisco, Sierra Club Books.

Carnegie Commission on Preventing Deadly Conflict (1997), Preventing Deadly Conflict: Final Report, New York, Carnegie Corporation.

Collier, Paul and Hoeffler, Anke (2002), 'Greed and Grievance in Civil Wars,' Washington, D.C., World Bank, unpublished paper. Available at:

http://128.8.56.16/Docs/docs/ppc_ideas/collier_hoeffler-greed_grievance.pdf.

Commission for Environmental Cooperation (1996), Potential NAFTA Effects: Claims and Arguments, 1991-94, Montreal: Commission for Environmental Cooperation, Environment and Trade Series No. 2. Available at:

http://www.cec.org/files/pdf/ECONOMY/claimse_EN.pdf

Conroy, Michael (2001), 'Can Advocacy-Led Certification Systems Transform Global Corporate Practices? Evidence, and Some Theory,' Amherst, Massachusetts, Political Economy Research Institute, Working Paper No. 21. Available at:

http://www.umass.edu/peri/pdfs/WP21.pdf.

Daly, Herman (1993), 'The Perils of Free Trade,' Scientific American, November, pp. 5057.

D’Arista, Jane and Boyce, James K. (2002), 'Where Credit is Due: Allocating Credit to Advance Environmental Goals,' Challenge, 45(3), 58-82.

Dimitri, Carolyn and Greene, Catherine (2002), 'Recent Growth Patterns in the U.S. Organic Foods Market,' U.S. Department of Agriculture, Economic Research Service, Market and Trade Economics Division and Resource Economics Division, Agriculture Information Bulletin Number 777.

Economist, The (1992), 'Let Them Eat Pollution,' 8 February, p. 66.

Esty, Daniel C. (1994), Greening the GATT: Trade, Environment, and the Future, Washington, D.C., Institute for International Economics.

Gale, Fred (2002), 'Caveat Certificatum: The Case of Forest Certification,' in T. Princen, M. Maniates and K. Conca, eds., Confronting Consumption, Cambridge, Massachusetts, MIT Press, 275-299.

Griffin, Keith (2003), 'Economic Globalization and Institutions of Global Governance,' Development and Change, 34, 789-807.

Haas, Peter (2003), 'Confronting the Global Governance Deficit,' Amherst, Massachusetts: University of Massachusetts, Department of Political Science. Unpublished paper. 
Haas, Peter (2002), 'Environment: Pollution,' in P.J. Simmons and C. de J. Oudraat, eds., Managing Global Issues: Lessons Learned. Washington, DC: Carnegie Endowment for International Peace, pp. 310-353.

Haas, Peter (1992), 'Banning Chlorofluorocarbons: Epistemic Community Efforts to Protect Stratospheric Ozone,' International Organization, 46(1), 187-224.

Hall, Anthony (1997), Sustaining Amazonia: Grassroots Action for Productive Conservation, Manchester, Manchester University Press.

Harbaugh, William, Levinson, Arik and Wilson, David (2000), 'Reexamining the Empirical Evidence for an Environmental Kuznets Curve,' Cambridge, MA: National Bureau of Economic Research, Working Paper 7711, May.

Hettige, H., Mani, M. and Wheeler, D. (2000), 'Industrial Pollution in Economic Development: The Environmental Kuznets Curve Revisited,' Journal of Development Economics, 62, 445-476.

Hogenboom, Barbara (1998), Mexico and the NAFTA Environment Debate: The Transnational Politics of Economic Integration, Utrecht, International Books.

Intergovernmental Panel on Climate Change (2001), 'Climate Change 2001: Impacts, Adaptation, and Vulnerability: Summary for Policymakers,' approved by IPCC Working Group II in Geneva, 13-16 February.

Jaffe, Adam. B., et al. (1995), 'Environmental Regulation and the Competitiveness of U.S. Manufacturing: What Does the Evidence Tell Us?' Journal of Environmental Literature, 33(1), 132-163.

Jänicke, Martin (1990), State Failure: The Impotence of Politics in Industrial Society, College Park, Pennsylvania State University Press.

Keenan, Karyn, Jose de Echave, and Ken Traynor (2003), 'Mining and Communities: Poverty Amidst Wealth,' paper presented at the International Conference on Natural Assets, Tagaytay City, Philippines, January. Available at: http://www.umass.edu/peri/pdfs/CDP3.pdf.

Khanna, Madhu, Quimio, Wilma Rose H., and Bojilova, Dora (1998), 'Toxic Release Information: A Policy Tool for Environmental Protection,' Journal of Environmental Economics and Management, 36, 243-266.

Konar, Shameek and Cohen, Mark A. (1995), 'Information as Regulation: The Effect of Community Right to Know Laws on Toxic Emissions,' Journal of Environmental Economics and Management,32,109-124. 
Kuznets, Simon (1963), 'Quantitative Aspects of the Economic Growth of Nations,' Economic Development and Cultural Change, 11(2/II), 1-80.

Lipschutz, Ronnie D. with Mayer, Judith (1996), Global Civil Society and Global Environmental Governance, Albany, State University of New York Press.

Low, Patrick and Yeats, Alexander (1992), 'Do “Dirty” Industries Migrate?' in P. Low, ed., International Trade and the Environment, Washington, D.C., World Bank Discussion Paper 159.

Maizels, A. (1992), Commodities in Crisis: The Commodity Crisis of the 1980s and the Political Economy of International Commodity Prices, Oxford, Clarendon Press.

Maizels, A. (1995), 'The functioning of international markets for primary commodities: Key policy issues for developing countries,' in UNCTAD, International Monetary and Financial Issues for the 1990s: Research Papers for the Group of Twenty-Four, Volume V, New York and Geneva, United Nations.

Meidinger, Errol E. (2001), 'Environmental Certification Programs and U.S. Environmental Law: Closer Than You May Think,' Environmental Law Reporter, 31, 10162-10179.

Mol, Arthur P.J. (2001), Globalization and Environmental Reform: The Ecological Modernization of the Global Economy. Cambridge, MA, MIT Press.

Muradian, Roldan, and Martinez-Alier, Joan (2001), 'Trade and the Environment: From a “Southern” Perspective,' Ecological Economics, 36, 281-297.

Myers, Norman (1993), Ultimate Security: The Environmental Basis of Political Stability, New York, Norton.

Neumayer, Eric (2002), 'Do Democracies Exhibit Stronger International Environmental Commitment? A Cross-Country Analysis,' Journal of Peace Research, 39(2), 139-164.

Opschoor, Johannes B. (1992), 'Sustainable Development, the Economic Process and Economic Analysis,' in J.B. Opschoor, ed., Environment, Economy and Sustainable Development, Amsterdam, Wolters-Noordhoff.

Opschoor, Johannes B. (2001), 'Economic Development in a Neoliberal World: Unsustainable Globalization?' in M. Munasinghe, O. Sunkel and C. de Miguel, eds., The Sustainability of Long-Term Growth: Socioeconomic and Ecological Perspectives, Cheltenham, Edward Elgar, 72-92.

Pargal, Sheoli and Wheeler, David (1996), 'Informal Regulations in Developing Countries: Evidence from Indonesia,' Journal of Political Economy, 104(6), 1314-1327. 
Pargal, Sheoli et al. (1997), 'Formal and Informal Regulation of Industrial Pollution: Comparative Evidence from Indonesia and the United States,' World Bank Economic Review, 11(3): 433-450.

Pastor, Manuel (2003), 'Building Social Capital to Protect Natural Capital: The Quest for Environmental Justice,' in James K. Boyce and Barry G. Shelley, eds., Natural Assets: Democratizing Environmental Ownership, Washington, D.C., Island Press, 77-97.

Pastor, Manuel, Sadd, Jim, and Hipp, John (2001), 'Which Came First? Toxic Facilities, Minority Move-in, and Environmental Justice,' Journal of Urban Affairs, 23, 1-21.

Petrini, Carlo, ed. (2003), Slow Food, New York, Columbia University Press.

Pinderhughes, Raquel (2003), 'Poverty and the Environment: The Urban Agriculture Connection,' in James K. Boyce and Barry G. Shelley, eds., Natural Assets:

Democratizing Environmental Ownership, Washington, D.C., Island Press, 299-312.

Polanyi, Karl (1957 [1944]), The Great Transformation: The Political and Economic Origins of our Time, Boston, Beacon Press.

Porter, Gareth (1999), "Trade Competition and Pollution Standards: "Race to the Bottom" or 'Stuck at the Bottom"?' Journal of Environment and Development, 8(2), 133-151.

Princen, Thomas (1997), 'The Shading and Distancing of Commerce: When Internalization Is Not Enough,' Ecological Economics, 20, 235-253.

Rauscher, Michael (1994), 'On Ecological Dumping,' Oxford Economic Papers, 46, 822840 .

Revkin, Andrew C. (2002), 'Climate Talks Shift Focus to Deal With Changes,' New York Times, 3 November, p. 10.

Rich, Richard C., Conn, W. David, and Owens, William L. (1993), “'Indirect Regulation” of Environmental Hazards Through the Provision of Information to the Public: The Case of SARA, Title III," Policy Studies Journal, 1(1),16-34.

Sachs, Wolfgang, et al. (1998), Greening the North: Post-Industrial Blueprint for Ecology and Equity, London, Zed.

Scruggs, Lyle A. (1998), 'Political and Economic Inequality and the Environment,' Ecological Economics, 26, 259-275.

Sen, Amartya (1975), Employment, Technology, and Development, Oxford: Oxford University Press.

Singh, Ajit (2004), 'Labour Standards and the "Race to the Bottom", in this issue. 
Sonnenfeld, David A. and Mol, Arthur P.J. (2002), 'Globalization and the Transformation of Environmental Governance,' American Behavioral Scientist, 45(9), 1318-1339.

Soros, George (2002), ‘Transparent Corruption,’ Financial Times, 13 June, p. 21.

Spaargaren, Gert and Mol, Arthur P.J. (1992), 'Sociology, Environment, and Modernity: Ecological Modernisation as a Theory of Social Change,' Society and Natural Resources, 5, 323-344.

Stewart, Frances (2002), 'Horizontal Inequalities: A Neglected Dimension of Development,' Oxford, Queen Elizabeth House, Working Paper No. 81.

Stockholm International Peace Research Institute (SIPRI) (1976), Ecological Consequences of the Second Indochina War, Stockholm, SIPRI.

Stonich, Susan and Bailey, Conner (2000), 'Resisting the Blue Revolution: Contending Coalitions Surrounding Industrial Shrimp Farming,' Human Organization, 59(1), 23-36.

Stonich, Susan and Vandergeest, Peter (2001), 'Violence, Environment, and Industrial Shrimp Farming,' in Michael Watts and Nancy Peluso, eds., Violent Environments, Ithaca, Cornell University Press, 261-286.

Sutcliffe, Bob (2004), 'World Inequality and Globalization,' in this issue.

Sutcliffe, Bob (2003), 'A More or Less Unequal World? World Income Distribution in the $20^{\text {th }}$ Century,' Amherst, MA, Political Economy Research Institute, Working Paper No. 54. Available at: http://www.umass.edu/peri/pdfs/WP54.pdf.

Swedish Committee for Afghanistan (1988), The Agricultural Survey of Afghanistan: First Report, Peshawar, Swedish Committee for Afghanistan.

Szasz, Andrew and Meuser, Michael (1997), 'Environmental Inequalities: Literature Review and Proposals for New Directions in Research and Theory,' Current Sociology, 45(3), 99-120.

Thrupp, Lori Ann (1998), Cultivating Diversity: Agrobiodiversity and Food Security, Washington, D.C., World Resources Institute.

Tietenberg, Tom and Wheeler, David (2000), 'Empowering the Community: Information Strategies for Pollution Control,' in H. Folmer et al., eds., Frontiers of Environmental Economics, Cheltenham, Edward Elgar.

Torras, Mariano and Boyce, James K. (1998), 'Income, Inequality, and Pollution: A Reassessment of the Environmental Kuznets Curve,' Ecological Economics, 25, 147-160. 
UNICEF (1996), The State of the World's Children 1996, New York: UNICEF.

UN Secretary-General (1992), An Agenda for Peace, New York, United Nations, Report of the Secretary-General, 17 June. Available at:

http://www.un.org/Docs/SG/agpeace.html.

Weale, A. (1992), The New Politics of Pollution, Manchester: Manchester University Press.

Weidner, Helmut and Jänicke, Martin (2002), 'Environmental Capacity Building in a Converging World,' in H. Weidner and M. Jänicke, eds., Capacity Building in National Environmental Policy: A Comparative Study of 17 Countries, Berlin, Springer, 409-443.

Weiner, Tim (2002), 'In Corn's Cradle, U.S. Imports Bury Family Farms,' New York Times, 26 February, p. A4.

Wilkes, H. Garrison (1992), Strategies for Sustaining Crop Germplasm Preservation, Enhancement, and Use, Washington, D.C., Consultative Group for International Agricultural Research.

World Bank (1992), World Development Report 1992: Development and the Environment, Oxford, Oxford University Press.

World Bank (1998), Post-Conflict Reconstruction: The Role of the World Bank, Washington, D.C., World Bank.

Young, Oran (1994), International Governance: Protecting the Environment in a Stateless Society, Ithaca, Cornell University Press.

Zarsky, Lyuba (1997), 'Stuck In the Mud? Nation-States, Globalization and the Environment,' Paper prepared for the Globalization and Environment Study, OECD Economics Division, The Hague, May. Available at:

http://www.nautilus.org/papers/enviro/zarsky_mud.html.

Zarsky, Lyuba (1999), 'Havens, Halos and Spaghetti: Untangling the Evidence about Foreign Direct Investment and the Environment,' Paper presented at the Conference on Foreign Direct Investment and the Environment, OECD Environment Directorate, The Hague, January. Available at:

http://www.nautilus.org/papers/enviro/zarsky oecdfdi.html. 
Figure 1: Environmental Convergence: Four Scenarios

\begin{tabular}{|c|c|c|}
\hline 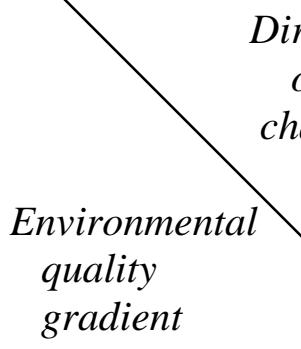 & $\begin{array}{c}\text { 'Harmonization } \\
\text { upward' }\end{array}$ & 'Race to the bottom' \\
\hline North $>$ South & $\begin{array}{l}\text { Ecological } \\
\text { modernization }\end{array}$ & $\begin{array}{l}\text { Environmental } \\
\text { protectionism }\end{array}$ \\
\hline South $>$ North & $\begin{array}{l}\text { Greening the } \\
\text { North }\end{array}$ & $\begin{array}{l}\text { Environmental } \\
\text { imperialism }\end{array}$ \\
\hline
\end{tabular}


Figure 2: Environmental Degradation, Income Inequality, and Per Capita Income

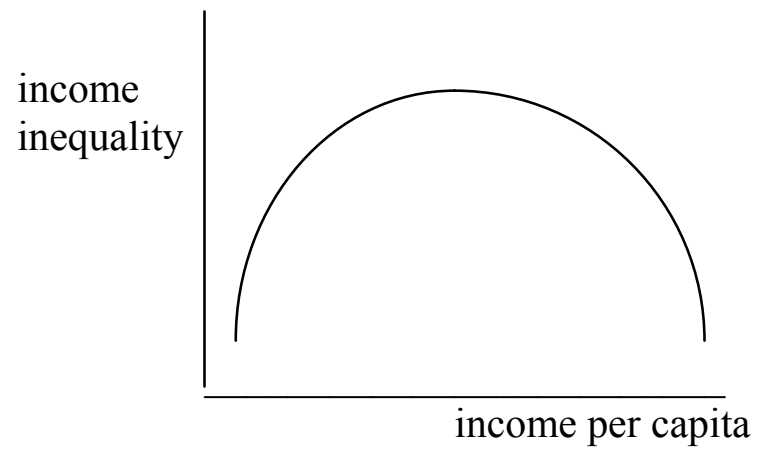

(a) The 'Kuznets curve'

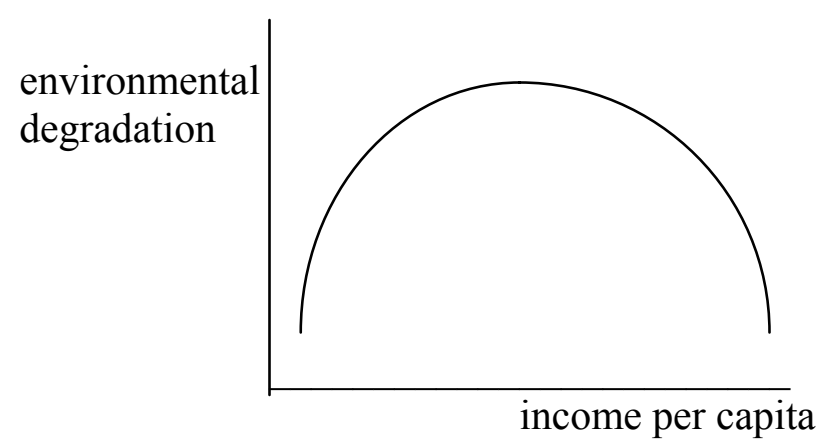

(b) The 'environmental Kuznets curve'

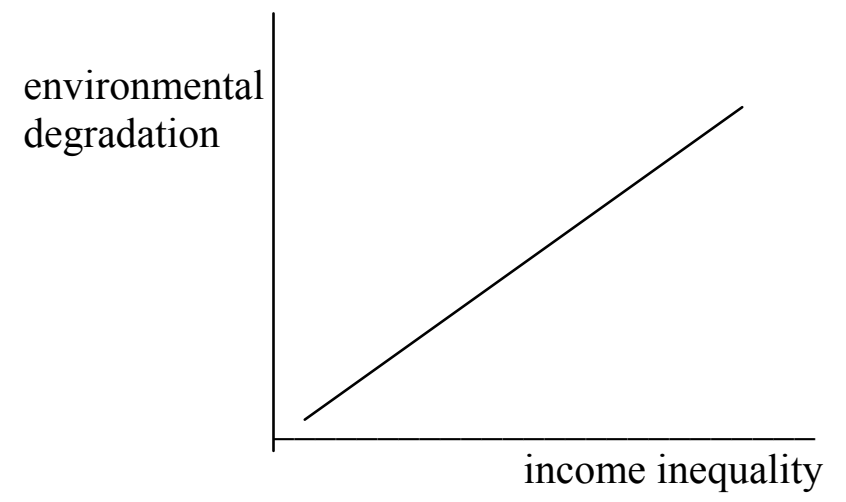

(c) Environment-inequality relation 
Table 1: List of Major International Environmental Agreements

\begin{tabular}{|c|c|c|}
\hline Agreement & Date & Issue addressed \\
\hline $\begin{array}{l}\text { International Convention for } \\
\text { the Regulation of Whaling }\end{array}$ & 1946 & Whale depletion \\
\hline Nuclear Test Ban Treaty & 1962 & $\begin{array}{l}\text { Atmospheric nuclear } \\
\text { weapons testing }\end{array}$ \\
\hline $\begin{array}{l}\text { Biological and Toxic } \\
\text { Weapons Treaty }\end{array}$ & 1972 & $\begin{array}{l}\text { Chemical and biological } \\
\text { weapons }\end{array}$ \\
\hline London Convention & 1972 & Ocean pollution \\
\hline Montreal Protocol & 1987 & Ozone-layer depletion \\
\hline Basel Convention & 1989 & $\begin{array}{l}\text { Transport of hazardous } \\
\text { wastes }\end{array}$ \\
\hline Convention on Biological Diversity & 1992 & Biodiversity loss \\
\hline Kyoto Protocol & 1997 & $\begin{array}{l}\text { Carbon emissions and } \\
\text { global climate change }\end{array}$ \\
\hline Mine Ban Treaty & 1997 & Landmines \\
\hline
\end{tabular}

